University of Nebraska - Lincoln

DigitalCommons@University of Nebraska - Lincoln

USDA National Wildlife Research Center - Staff Publications
U.S. Department of Agriculture: Animal and Plant Health Inspection Service

2009

\title{
Experimental Infection of Cliff Swallows (Petrochelidon pyrrhonota) with Varying Doses of West Nile Virus
}

\author{
Paul T. Oesterle \\ Nicole M. Nemeth \\ Kaci K. VanDalen \\ USDA/APHIS/WS National Wildlife Research Center, kaci.vandalen@aphis.usda.gov \\ Heather Sullivan \\ USDA/APHIS/WS National Wildlife Research Center, Heather.Sullivan@aphis.usda.gov \\ Kevin T. Bentler
}

See next page for additional authors

Follow this and additional works at: https://digitalcommons.unl.edu/icwdm_usdanwrc

Part of the Environmental Sciences Commons

Oesterle, Paul T.; Nemeth, Nicole M.; VanDalen, Kaci K.; Sullivan, Heather; Bentler, Kevin T.; Young, Ginger R.; McLean, Robert G.; Clark, Larry; Smeraski, Cynthia; and Hall, Jeffrey S., "Experimental Infection of Cliff Swallows (Petrochelidon pyrrhonota) with Varying Doses of West Nile Virus" (2009). USDA National Wildlife Research Center - Staff Publications. 955.

https://digitalcommons.unl.edu/icwdm_usdanwrc/955

This Article is brought to you for free and open access by the U.S. Department of Agriculture: Animal and Plant Health Inspection Service at DigitalCommons@University of Nebraska - Lincoln. It has been accepted for inclusion in USDA National Wildlife Research Center - Staff Publications by an authorized administrator of DigitalCommons@University of Nebraska - Lincoln. 


\section{Authors}

Paul T. Oesterle, Nicole M. Nemeth, Kaci K. VanDalen, Heather Sullivan, Kevin T. Bentler, Ginger R. Young, Robert G. McLean, Larry Clark, Cynthia Smeraski, and Jeffrey S. Hall 


\title{
Experimental Infection of Cliff Swallows (Petrochelidon pyrrhonota) with Varying Doses of West Nile Virus
}

\author{
Paul T. Oesterle,* Nicole M. Nemeth, Kaci VanDalen, Heather Sullivan, Kevin T. Bentler, Ginger R. Young, \\ Robert G. McLean, Larry Clark, Cynthia Smeraski, and Jeffrey S. Hall \\ United States Department of Agriculture, Wildlife Services, National Wildlife Research Center, Fort Collins, Colorado; \\ Department of Microbiology, Pathology, and Immunology; Department of Biomedical Sciences, Colorado State University,
} Fort Collins, Colorado; USGS National Wildlife Health Center, Madison, Wisconsin

\begin{abstract}
Cliff swallows (Petrochelidon pyrrhonota) were inoculated with differing doses of West Nile virus (WNV) to evaluate their potential role as reservoir hosts in nature. Swallows often nest in large colonies in habitats and months associated with high mosquito abundance and early WNV transmission in North America. Additionally, cliff swallow diet consists of insects, including mosquitoes, leading to an additional potential route of WNV infection. The average peak viremia titer among infected cliff swallows was $10^{6.3}$ plaque-forming units (PFU)/mL serum and the reservoir competence index was 0.34 . There was no correlation between dose and probability of becoming infected or viremia peak and duration. Oral shedding was detected from 2 to 14 days post-inoculation with an average peak titer of $10^{4.4} \mathrm{PFU} / \mathrm{swab}$. These results suggest that cliff swallows are competent reservoir hosts of WNV and therefore, they may play a role in early seasonal amplification and maintenance of WNV.
\end{abstract}

\section{INTRODUCTION}

West Nile virus (WNV; family Flaviviridae, genus Flavivirus) is maintained in nature through mosquito-bird transmission cycles, which are reinitiated annually in temperate areas after extended periods of cold temperatures. ${ }^{1}$ Numerous avian species in the order Passeriformes are considered competent WNV reservoir hosts, but there is a wide range of viremic responses and hence differential reservoir competence indices within this order, and within families. ${ }^{2,3}$ Thus far, information regarding WNV infection of members of the family Hirundinidae (e.g., swallows and martins), order Passeriformes, are lacking. In addition, free-ranging birds are exposed to a range of WNV doses via mosquito bite, and knowledge of potential dosedependent responses among a variety of avian species is relevant to understanding transmission dynamics. ${ }^{4}$

Aspects of cliff swallow (Petrochelidon pyrrhonota) natural history and breeding ecology may lead to involvement of this species arbovirus transmission. The cliff swallow breeding range includes most of North America, ${ }^{5}$ largely overlapping with WNV-endemic areas, ${ }^{6}$ and the breeding season coincides with early WNV transmission in northern Colorado and much of the temperate United States. ${ }^{7}$ This species nests synchronously in large colonies of up to 3,500 active nests, with an average of 3 to 4 nestlings per nest. ${ }^{5}$ Colonies are often concentrated within habitats that contain an abundance of mosquitoes, ${ }^{8}$ which also comprise a portion of the swallow diet. ${ }^{9}$ Therefore, thousands of swallows are potentially exposed to WNV-infected mosquitoes either by blood feeding or ingestion within a given season. This hypothesis is supported by evidence of high exposure rates in nestling and adult cliff swallows shortly after the introduction of WNV to northern Colorado (Clark and others, unpublished data).

To better understand the effects of WNV in cliff swallows, and the potential involvement of these birds in transmission, study objectives were aimed at evaluating viremia profiles and calculating a reservoir competence index for cliff swal-

\footnotetext{
*Address correspondence to Paul T. Oesterle, National Wildlife Research Center, USDA/APHIS/WS, Fort Collins, CO 80521. E-mail: Paul.T.Oesterle@aphis.usda.gov
}

lows, determining whether there was a WNV dose-dependent response in swallows, evaluating oral shedding of WNV after experimental infection, and assessing morbidity and mortality rates among WNV-inoculated cliff swallows.

\section{METHODS}

Swallow capture and husbandry. In July of 2004, 49 cliff swallow nestlings were collected from four colonies near Fort Collins, Colorado. The nestlings, aged 8-17 days posthatch $^{10}$ were transported to the National Wildlife Research Center (NWRC) in Fort Collins. The birds were banded, dusted with Drione (Bayer Environmental Science, Montvale, $\mathrm{NJ})$ to remove external parasites, thoroughly inspected to confirm parasite removal, and placed in artificial nests (3-5 birds/nest), each within a separate cage $(61 \times 43 \times 33 \mathrm{~cm})$. The maintenance and care of swallows was in compliance with the National Institutes of Health guidelines for the humane use of laboratory animals, and the research was conducted under Institutional Animal Care and Use approval.

Hand-feeding of nestlings began approximately 1 hour after arrival. Initially, nestlings were fed hourly from 6:00 AM to 6:00 PM with one of five rotating food items (i.e., scrambled egg, dry cat food, wax worms, cricket abdomens, and mealworm guts). Food items were supplemented with ground cuttlefish bone and Vitaflight vitamin supplement (Virbac Animal Health, Fort Worth, TX). Birds were weighed daily with a digital gram scale (accuracy of $0.1 \mathrm{~g}$ ) before the first feeding and were fed $\sim 60 \%$ of body weight each day. The number of hand feedings per day was gradually reduced from 13 to none over 45 to 65 days as the birds matured. Once feedings had been reduced to five per day, food pans of egg, cat food, live mealworms, wax worms, and small crickets were provided to each cage, and perches were added. Forty-one cliff swallow nestlings survived this husbandry period and were included in the experiment.

Sample collection and preparation, and experimental inoculation. Approximately 7 weeks after capture, birds were bled by jugular venipuncture for assessment of anti-WNV antibody status. When these fledglings were independently feeding, they were transferred to a Biosafety Level-3 Laboratory (BSL-3) 
at Colorado State University in Fort Collins. Thirty-eight cliff swallows were divided among four treatment groups ( $N=8-10 /$ group), and three additional birds served as noninoculated controls. Negative control birds were housed in a separate cage from inoculates, but within the same room.

All 41 birds were bled again just before inoculation ( $\sim 3$ weeks after initial blood collection) to confirm WNV serostatus. Only birds that were negative for anti-WNV antibodies (seronegative upon serial collection of sera, collected 3 weeks apart) and had no evidence of active WNV infection (e.g., viremia or oral shedding) were included in the experiment. Birds within treatment groups were administered a subcutaneous injection over the pectoral muscle containing one of four doses $\left(10^{1.0}, 10^{1.5}, 10^{2.5}\right.$, or $10^{3.5}$ plaque-forming units [PFU]) of WNV strain NY99-4132 in 0.1 mL BA-1 medium (M199Hank's salts, $1 \%$ bovine serum albumin, $350 \mathrm{mg} / \mathrm{L}$ sodium bicarbonate, 100 units $/ \mathrm{mL}$ penicillin, $100 \mu \mathrm{g} / \mathrm{mL}$ streptomycin, $2.5 \mu \mathrm{g} / \mathrm{mL}$ fungizone in $0.05 \mathrm{M}$ Tris, $\mathrm{pH}$ 7.6). The WNV strain used was originally isolated from an infected crow and passaged once in Vero cells, once in C6/36 mosquito cells, and once in baby hamster kidney-21 cells. The three negative control birds received a subcutaneous injection of BA-1 $(0.1 \mathrm{~mL})$.

Sampling scheme and sample preparation. The treatment and control groups were randomly divided into two cohorts, each of which was sampled on alternate days (i.e., 1,3,5,7,14 or $2,4,6,8,15$ days post-inoculation [DPI]). Sampling consisted of jugular venipuncture to obtain $0.1 \mathrm{~mL}$ of blood, and swabbing the oral cavity using cotton-tipped swabs $(0.28 \mathrm{~cm}$ diameter tip; Fisher Scientific, Pittsburgh, PA). Blood was immediately placed in serum separator tubes, allowed to clot for 30 to 60 minutes at room temperature, and centrifuged $(10,000 \times g$ for $5 \mathrm{~min}$ ) for separation of serum. Oral swabs were placed into cryogenic vials with $1.25 \mathrm{~mL}$ of BA-1. All samples were frozen at $-80^{\circ} \mathrm{C}$ until testing.

Surviving birds were euthanized by sodium pentobarbital overdose on 17 DPI. A subset of birds that died during the study, and a subset of those euthanized at the conclusion of the study (2-3 birds/treatment group), were necropsied $(N=12)$. Tissues (heart, brain, and kidney) and oral swabs were aseptically collected and placed in $1 \mathrm{~mL} \mathrm{BA-1}$ as a $10 \%$ tissue suspension, homogenized and centrifuged as previously described, ${ }^{11}$ and frozen at $-80^{\circ} \mathrm{C}$.

Laboratory testing and methods. Pre-inoculation sera and oral swabs were tested by reverse transcription-polymerase chain reaction (RT-PCR) for detection of WNV RNA to assess previous WNV exposure. In addition, RT-PCR was used to confirm viral plaques as WNV in a subset of samples collected post-inoculation. Methods for RT-PCR followed those of Lanciotti and others. ${ }^{12}$ Briefly, viral RNA was extracted from serum and cell suspensions using the QIAamp Viral RNA Mini Kit (QIAGEN Valencia, CA), and amplified using the Taqman One-Step RT-PCR system (Applied Biosystems Foster City, $\mathrm{CA}$ ) with primers and probes as previously described. ${ }^{12}$

Vero-cell plaque assay was performed on pre-inoculation and post-inoculation (1-8 DPI) sera and oral swabs, as well as tissue homogenates (8-17 DPI) as described in Komar and others. ${ }^{2}$ Briefly, Vero cell monolayers in 6-well plates were inoculated in duplicate with $0.1 \mathrm{~mL}$ of sample per well. The plates were incubated for 1 hour at $37^{\circ} \mathrm{C}$ after which the cells were overlaid with $3 \mathrm{~mL} /$ well of $0.5 \%$ agarose in minimum essential medium (MEM) containing fungizone, and antibiotics. Two days later, cells were overlaid with a second 3-mL overlay con- taining $0.004 \%$ neutral red dye. Viral plaques were counted on the third and fourth days of incubation. The minimum titers of WNV detection by virus isolation were $10^{1.7} \mathrm{PFU} / \mathrm{mL}$ serum, $10^{0.7} \mathrm{PFU} / \mathrm{swab}$, and $10^{1.7} \mathrm{PFU} / \mathrm{g}$ tissue. Viral PFU observed by PA were harvested and confirmed as WNV by RT-PCR.

Plaque reduction neutralization assays were performed on sera collected pre-inoculation ( 7 and 10 weeks after capture) and post-inoculation (14-15 DPI) for assessment of WNV serostatus. ${ }^{13} \mathrm{~A}$ challenge dose of $\sim 100$ PFU WNV strain NY99-4132 was used for the plaque reduction neutralization test (PRNT), with the same positive control sera used for all assays. Serum samples that showed $\leq 60 \%$ neutralization at a 1:10 dilution were considered negative for anti-WNV antibodies, and post-exposure samples were serially diluted (2-fold) to determine reciprocal endpoint $90 \%$ neutralization $\left(\mathrm{PRNT}_{90}\right)$ titers.

Statistical analyses and calculations. The reservoir competence index was calculated for all cliff swallows as a group, and for each dose-treatment group. Infectiousness was the sum of the daily probabilities that a mosquito will become infectious for WNV after biting a bird ${ }^{2}$ and was calculated as described by Kilpatrick and others, ${ }^{3}$ where $\%$ infectiousness $=0.1349$ $\times \log _{10}$ (viremia) -0.6235 . The threshold for infectiousness (based on data from Culex pipiens) was a viremia titer of $10^{4.62} \mathrm{PFU} / \mathrm{mL}$ serum. The probability that a bird with viremia titers below this threshold will transmit WNV to a mosquito is negligible; therefore, the \% infectiousness for viremia below this threshold was considered zero. ${ }^{3}$ Infectiousness was calculated for every day that viremia titers were above the threshold for each individual bird; infectiousness was then averaged over all individuals, and daily averages were summed. The summed daily averages of each treatment (e.g., dose) group and of the entire WNV-inoculated group represented the reservoir competence index of the group and species, respectively. Because each individual bird was sampled every other day, daily averages (from 1 to $8 \mathrm{DPI}$ ) were calculated for all individuals sampled on a given day.

Numerous variables (i.e., rate of infection, peak viremia, DPI of peak viremia, duration of viremia, rate of infectiousness, infectiousness, duration of infectiousness, reservoir competence index, and peak oral shedding) were analyzed as a function of viral dose by analysis of variance (ANOVA) using Proc GLM (SAS Institute, Cary, NC). These variables (with peak viremia and oral shedding in $\log _{10}$ PFU, and duration of viremia and duration of infectiousness in days) were treated as dependent variables, and dose was a fixed variable. Samples from which no infectious virus was detected were quantified as zero. Birds that were inoculated but had no detectable viremia or shedding and failed to seroconvert by 14 DPI were not considered infected, and therefore, were not included in the analysis; consequently, the sample sizes were from 3 to 5 birds/ dosage group/day. Viral titers in tissues were analyzed separately as a function of viral dose by ANOVA using Proc GLM, with viral titer in tissues treated as a dependent variable, and dose as a fixed variable.

\section{RESULTS}

Viremia, oral shedding, serology, and tissue tropism. Before inoculation, all nestlings were negative for anti-WNV antibodies and for WNV in oral swabs and sera. The majority $(89.5 \%$; $34 / 38$ ) of WNV-inoculated nestlings developed detectable 
viremia, with an average peak titer of $10^{6.3} \mathrm{PFU} / \mathrm{mL}$ serum (range: $10^{3.7-6.9}$, Table 1, Figure 1). Of the four birds that failed to become infected, two were in the lowest dosage ( $\left.10^{1.0} \mathrm{PFU}\right)$ group and one was in each of the higher dosage groups $\left(10^{1.5}\right.$ and $\left.10^{2.5} \mathrm{PFU}\right)$. The duration of detectable viremia among birds that survived ranged from 1 to 5 DPI, although viremia was detectable in $44 \%$ of birds $(8 / 18)$ by 5 DPI. Viremia was detected on 8 DPI in one bird that died on that same day. Oral shedding (average peak of $10^{4.5} \mathrm{PFU} / \mathrm{swab}$ ) was detected in all viremic birds; the range of shedding was from 2 to 14 DPI but typically occurred from 3 to 8 DPI (Figure 2). All birds that had detectable viremia and survived > 8 DPI had developed WNV neutralizing antibodies by 14-15 DPI, with PRNT $_{90}$ titers ranging from 10 to 640 .

No infectious WNV was observed in oral swabs, heart, or brain of birds euthanized on 17 DPI $(N=11)$, or in a bird that died on 8 DPI. However, between 10 $0^{2.2-3.9} \mathrm{PFU} / \mathrm{gram}$ of tissue was present in kidney of $45 \%$ (5/11) of birds euthanized and necropsied on 17 DPI.

Statistical results and reservoir competence index. There was no significant difference between the treatment (i.e., dose) groups when comparing rate of infection, peak viremia, DPI of peak viremia, duration of viremia, rate of infectiousness, infectiousness, duration of infectiousness, reservoir competence index, and peak oral shedding (Table 1). Additionally, there was no significant difference in the number of tissues positive among treatment groups (ANOVA; $P=0.15$ ). The reservoir competence index for each of the four treatment groups was statistically similar (range 0.26-0.45); the reservoir competence index for all inoculated cliff swallows was 0.34 .

Morbidity and mortality. Two birds exhibited clinical signs (e.g., lethargy, fluffed feathers) on 4 DPI but appeared to recover within $\leq 24$ hours after these observations, and subsequently appeared clinically normal until euthanasia on 17 DPI. Peak viremia titers in these birds were from $10^{6.6-6.9} \mathrm{PFU}$ and occurred on 1 and 3 DPI.

Three birds died during the study, two on 8 DPI and the third on 15 DPI. One bird that died on 8 DPI had a viremia titer of $10^{5.5} \mathrm{PFU} / \mathrm{mL}$ on $2 \mathrm{DPI}$; this titer subsequently declined to $10^{2.7} \mathrm{PFU} / \mathrm{mL}$ on $4 \mathrm{DPI}$ and was undetectable on $6 \mathrm{DPI}$; there was no detectable virus in tissues collected on 8 DPI. The other bird that died on 8 DPI exhibited morbidity from 6 to 8 DPI and viremia was detected from 2 to 8 DPI, with a peak titer of $10^{6.8} \mathrm{PFU} / \mathrm{mL}$ serum on 4 DPI. The bird that died on 15 DPI had detectable viremia on 1 and 3 DPI, with a peak titer of $10^{4.7} \mathrm{PFU} / \mathrm{mL}$ serum on $3 \mathrm{DPI}$; this bird seroconverted by 14 DPI.

\section{DISCUSSION}

The cliff swallow is in the order Passeriformes, which has been the focus of numerous WNV studies, and many species within this order are important in WNV transmission ecology and have likely played a role in the expanding geographic range of WNV., ${ }^{2,14-16}$ The cliff swallow has a broad geographic range, extending from central Alaska to Argentina; this range includes both wintering and breeding grounds visited during annual migration. ${ }^{5}$ Although this abundant species has ample opportunity for WNV exposure across its range, information regarding WNV infection in swallows is limited.

West Nile virus exposure rates, as well as susceptibility of cliff swallows to both oral- and arthropod-derived infection and associated morbidity and mortality, are not well understood. Cliff swallow carcasses in Colorado (1/2) and California $(5 / 38)$ tested positive for $\mathrm{WNV},{ }^{17,18}$ whereas sampling of freeranging adult cliff swallows during the 2004 breeding season in northern Colorado revealed a seroprevalence of $40 \%$ (173/429). In addition, oral swabs collected from 23\% (32/137) of cliff swallow nestlings during the 2003 breeding season, also in northern Colorado, tested positive for WNV by RT-PCR (Clark L and others, unpublished data). These field-acquired data suggest that cliff swallows may be commonly exposed to and infected with WNV, and if competent reservoir hosts, swallows may contribute to transmission maintenance and amplification.

Results from the present study suggest that the cliff swallow is a competent reservoir host of WNV. Infected swallows had an average peak viremia titer of $10^{6.3} \mathrm{PFU} / \mathrm{mL}$ serum; this peak titer is lower than those previously documented among passerines, though the duration of detectable viremia is similar to that of other passerine birds that survived infection. ${ }^{2}$ The reservoir competence index for the cliff swallow was relatively low $(\sim 0.34)$, similar to that of the northern mockingbird (Mimus polyglottos) and northern cardinal (Cardinalis cardinalis). ${ }^{3}$ In contrast, other common passerines such as the house sparrow (Passer domesticus), common grackle (Quiscalus quiscula), and blue jay (Cyanocitta cristata) each had a greater reservoir competence index ( 1.3-2.4), making these species

TABLE 1

Viremia, oral shedding, and reservoir competence index of experimentally West Nile virus-inoculated cliff swallows (Petrochelidon pyrrhonota) with a range of doses

\begin{tabular}{|c|c|c|c|c|c|c|c|c|c|}
\hline \multirow[b]{2}{*}{ Dosage $\left(\log _{10} \mathrm{PFU} \dagger\right)$} & \multirow[b]{2}{*}{$N$} & \multirow[b]{2}{*}{ Proportion infected } & \multicolumn{3}{|c|}{ Viremia (average/group) } & \multirow{2}{*}{$\begin{array}{c}\begin{array}{c}\text { Oral shedding } \\
\text { (average/group) }\end{array} \\
\begin{array}{c}\text { Peak } \\
\left(\log _{10} \mathrm{PFU} / \mathrm{mL} \text { swab }\right)\end{array}\end{array}$} & \multicolumn{2}{|c|}{$\begin{array}{l}\text { Minimum infectiousness } \\
\text { threshold* }\end{array}$} & \multirow[b]{2}{*}{$\begin{array}{c}\text { Reservoir } \\
\text { competence index§ }\end{array}$} \\
\hline & & & $\begin{array}{c}\text { Peak } \\
\left(\log _{10} \mathrm{PFU} / \mathrm{mL}\right. \\
\text { serum) }\end{array}$ & $\begin{array}{l}\text { Days } \\
\text { post-inoculation } \\
\text { at peak }\end{array}$ & $\begin{array}{c}\text { Average } \\
\text { duration (days) }\end{array}$ & & $\begin{array}{c}\begin{array}{c}\text { Proportion } \\
\text { attained }\end{array} \\
\end{array}$ & $\begin{array}{l}\text { Average duration } \\
\text { (days) }\end{array}$ & \\
\hline 1.0 & 10 & 0.80 & 6.5 & 2.6 & 2.5 & 5.0 & 0.88 & 1.0 & 0.40 \\
\hline 1.5 & 8 & 0.88 & 6.4 & 2.9 & 3.9 & 4.4 & 1.00 & 1.6 & 0.45 \\
\hline 2.5 & 10 & 0.90 & 5.8 & 2.9 & 3.0 & 3.5 & 1.00 & 1.1 & 0.27 \\
\hline 3.5 & 10 & 1.00 & 5.9 & 2.3 & 3.2 & 4.2 & 0.90 & 0.9 & 0.26 \\
\hline total & $38 \mathbb{1}$ & 0.89 & 6.3 & 2.6 & 3.1 & 4.4 & 0.94 & 1.1 & 0.34 \\
\hline$P$ value & & 0.5675 & 0.8650 & 0.8741 & 0.2360 & 0.6811 & 0.5830 & 0.4607 & 0.3495 \\
\hline
\end{tabular}

* Infectiousness represents the percent of mosquitoes (Culex pipiens) that become infected after feeding on a host as a function of host viremia, calculated as $0.1349 \times \log _{10}$ (viremia) -0.6235 .

The minimum threshold for infectiousness was $10^{4.62} \log _{10} \mathrm{PFU} / \mathrm{mL}$ serum; viremia titers below this threshold were not considered infectious to mosquitoes. ${ }^{3}$

$\dagger$ Plaque-forming units (PFU) of West Nile virus.

$\$$ Proportion attained represents infected birds that reached the minimum infectiousness threshold.

$\S$ Reservoir competence index is the summed daily averages of infectiousness of all individuals within each dosage group. ${ }^{3}$

I Four birds that failed to become infected after inoculation were excluded from values presented for viremia, oral shedding, infectiousness, and reservoir competence index.

" $P$ value from analysis of variance (ANOVA) testing for differences between dosage groups, with significance level $\alpha=0.05$. 


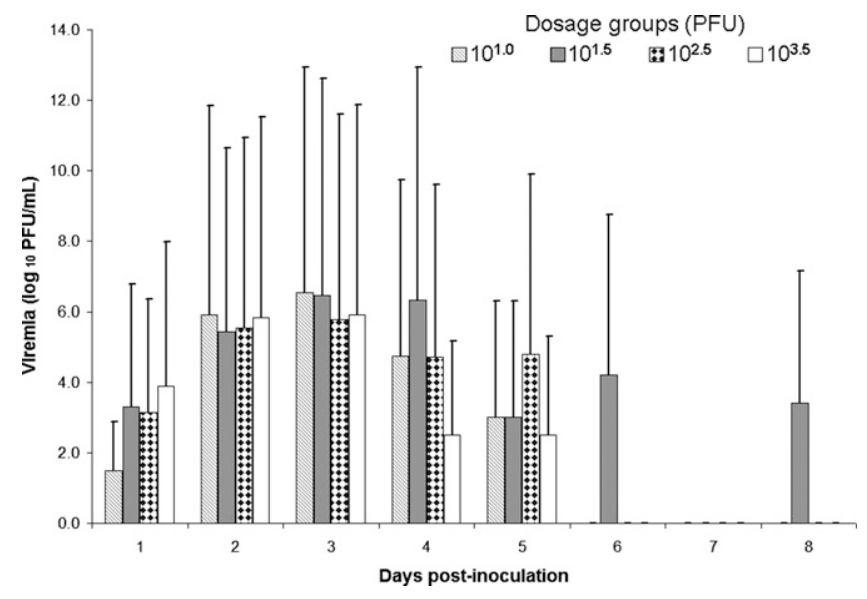

FIGURE 1. Viremia profiles with daily average for each of four West Nile virus dosage groups (upper $95 \%$ confidence interval presented).

more likely to infect mosquitoes. ${ }^{3}$ Although the reservoir competence index is a useful tool to compare the relative reservoir competence of vertebrate species for which viremia profiles are known, its application to a natural setting must be made with caution because the calculation is based solely on laboratory studies of Culex pipiens. ${ }^{19-21}$ West Nile virus transmission and ensuing infection of a host is likely dependent upon multiple factors, including but not limited to the availability and activity of competent vectors and hosts, as well as environmental variables such as weather patterns and habitat characteristics. $^{22}$

Various aspects of cliff swallow ecology may elevate their likelihood of WNV exposure. Swallow colonies are used by a variety of other passerines, the most common being the house sparrow. House sparrows are attracted to swallow colonies for nesting purposes, using cliff swallow nests at times when swallows are concurrently actively nesting. ${ }^{5}$ House sparrows are competent WNV reservoir hosts ${ }^{2}$ and are frequently exposed to WNV in various geographic regions..$^{1,23-25}$ Experimentally inoculated sparrows reached viremia titers of up to $\sim 10^{10}$ $\mathrm{PFU} / \mathrm{mL}$ serum, leading to a relatively high reservoir competence index for this species. ${ }^{1-3}$ Therefore, the presence of house

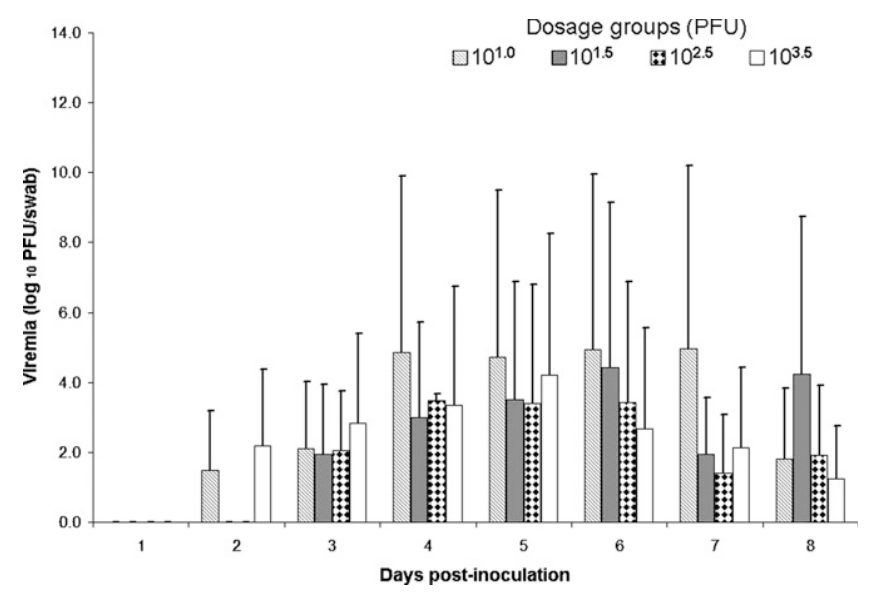

FIGURE 2. Oral shedding profiles with daily average for each of four West Nile virus dosage groups (upper $95 \%$ confidence interval presented). sparrows in cliff swallow colonies may lead to elevated WNV transmission levels, thereby increasing the likelihood of exposure to swallows. Cliff swallows may also be susceptible to oral WNV infection because a portion of their diet includes mosquitoes $^{9}$ and because experimental infection of a house finch (Carpodacus mexicanus) occurred by ingestion of an infectious mosquito. ${ }^{2}$ In addition, direct (e.g., oral) transmission of WNV could potentially occur from either parents to nestlings, or nest mate to nest mate.

Culex tarsalis mosquitoes are relatively common in northern Colorado and are known vectors of WNV ${ }^{26}$ The abundance of Cx. tarsalis has been positively associated with cliff swallow colonies, ${ }^{8}$ and cliff swallows have been identified as a blood meal source for this mosquito species. ${ }^{27}$ Culex tarsalis are a competent $\mathrm{WNV}$ vector and expectorate a wide range of viral titers (from $10^{0.8-3.6} \mathrm{PFU}$ ) when feeding or attempting to feed on its host $^{4}$; the saliva of experimentally inoculated $C x$. spp. mosquitoes contained from 10 $0^{0.5-3.7} \mathrm{PFU} \mathrm{WNV} /$ salivation. ${ }^{28}$ Because mosquitoes deliver a range of WNV doses, it is important to consider potential dose-dependent responses within the host. Reisen and others ${ }^{4}$ revealed that the inoculating WNV dose (range $<10^{0-4.2} \mathrm{PFU} / \mathrm{mL}$ ) did not affect peak viremia titers in house finches and mourning doves (Zenaidura macroura). In cliff swallows, there were no apparent differences in measured variables among the four dosage groups; however, because of small sample sizes and high variability among viremia titers, power was low (Figures 1 and 2). Unlike Reisen and others, ${ }^{4}$ some inoculated swallows failed to become infected; the reasons for which are unknown but may have been caused by delivered doses below the minimum threshold for infection or variation between delivered viral dose and titrated inoculum.

Various non-traditional arthropods (e.g., ticks) have demonstrated the ability to experimentally transmit WNV to birds and mice. ${ }^{29,30}$ The swallow bug (Oeciacus vicarious) is a hematophagous parasite that is closely associated with cliff swallow colonies and could serve as a potential alternate WNV vector (either biologic or mechanical). These bugs occupy swallow colonies year-round and feed primarily on cliff swallows, but also on other birds that occupy the nests, such as house sparrows. ${ }^{5,31}$ These parasites are potentially exposed to infectious WNV when feeding on viremic cliff swallows or other hosts as evidenced by WNV-positive swallow bugs collected during both summer and winter in northern Colorado (Clark L and others, unpublished data). In addition, bugs opportunistically feed on swallow nestlings, ${ }^{31}$ which may have higher peak viremia titers than adults ${ }^{32,33}$ and have a relatively long development period within the nest before fledging (i.e., 26 days) compared with other passerines. ${ }^{5}$ Furthermore, swallow bugs remain in nests year-round and if persistently infected with $\mathrm{WNV}$, could provide an overwintering mechanism for WNV, as they do for Buggy Creek virus. ${ }^{34}$ The WNV vector competence of the swallow bug, and therefore potential to infect the cliff swallow, has yet to be fully explored.

Apparent morbidity and mortality rates were relatively low in the cliff swallow compared with some passerines. ${ }^{2}$ Three swallows died after WNV inoculation; WNV was not considered the likely cause of death in two of these swallows based on early virus clearance and timing of death. Viremia was undetectable after 3 to 4 DPI, and both birds had relatively low peak viremia titers $\left(10^{4.7-5.5} \mathrm{PFU} / \mathrm{mL}\right.$ serum). One died on 8 DPI with no virus detected in tissues, and the other died on 15 DPI. 
However, it is possible that these birds overcame acute WNV infection, but suffered from more chronic but undetected effects of infection (e.g., histologic damage). The third swallow failed to clear WNV from the blood by 8 DPI at which time it died, suggesting that WNV may have been the primary cause of death. Considering these three birds as possible victims of WNV, the WNV-associated mortality rate among cliff swallows was between 2.6 and $7.9 \%$ (1-3 birds of 38). In addition, two birds that survived to the end of the study exhibited transient clinical signs (e.g., lethargy) on 4 DPI, but appeared to recover; both had relatively high peak viremia titers around the time of observed morbidity. Infectious WNV persisted in the kidneys of several apparently healthy swallows for up to 17 DPI, consistent with several other experimental studies in birds from which WNV was isolated from tissues (i.e., spleen, kidney, skin, heart, brain, and eye) at 15-43 DPI and 8-14 days post-viremia., 2,35,36

Given that cliff swallows are likely WNV reservoir competent and appear to have relatively low associated mortality, the role of this species in transmission should be further explored. Cliff swallows have ample opportunities for exposure to WNV because large numbers of birds, including many young birds, congregate in areas of abundant mosquito vectors during the breeding season, a scenario that could greatly amplify local transmission. Furthermore, the swallow diet consists entirely of insects, including mosquitoes, which could provide an additional infection route. Future research aimed at mosquito feeding rates on swallows and WNV prevalence among mosquitoes within swallow colonies, the possibility of virus transmission via swallow bugs and other non-traditional arthropod nest occupants, and efficiency of oral transmission among birds, will aid in the understanding and modeling the role of cliff swallows and other birds in WNV ecology.

\section{Received March 15, 2009. Accepted for publication July 31, 2009.}

Acknowledgments: We thank Richard Bowen for generously providing advice, laboratory and animal space, and WNV inoculum, and Kacy Cobble, Stacey Elmore, Nicole Mooers, and Lisa Kellihan for assistance in hand-rearing chicks.

Financial support: Funding for this work was provided by the U.S. Department of Agriculture and the U.S. Centers for Disease Control and Prevention (grant number 07-7488-0587) by the National Institutes of Health [grant number 1 RO1CI000219-01 (LC)] and by Colorado State University Infectious Disease Initiative (Office of Vice President for Research and Information Technology).

Authors' addresses: Paul T. Oesterle, Kaci VanDalen, Heather Sullivan, Kevin T. Bentler, Ginger R. Young, Robert G. McLean, and Larry Clark, National Wildlife Research Center, USDA/APHIS/ WS, Fort Collins, CO 80521, Tel: 970-266-6000, Fax: 970-266-6138, E-mails: Paul.T.Oesterle@aphis.usda.gov, Kaci.Vandalen@aphis.usda .gov, Heather.Sullivan@aphis.usda.gov, Kevin.T.Bentler@aphis.usda .gov, gpj2@cdc.gov, Robert.G.McLean@aphis.usda.gov, and Larry .Clark@aphis.usda.gov. Nicole M. Nemeth, National Wildlife Research Center, USDA/APHIS/WS, Fort Collins, CO 80521, Tel: 970-266-6000, Fax: 970-266-6138 and Department of Microbiology, Immunology, and Pathology, Colorado State University, Fort Collins, CO 805231683, E-mail: Nicole.M.Nemeth@aphis.usda.gov. Cynthia Smeraski, Department of Biomedical Sciences, 3801 West Rampart Road, Foothills Campus, Colorado State University, Fort Collins, CO 805231683,Tel: 970-491-5768, Fax: 970-491-3557,E-mail: Cynthia.Smeraski@ colostate.edu. Jeffrey S. Hall, National Wildlife Health Center, USGS, Madison, WI 53711, Tel: 608-270-2458,E-mail: jshall@usgs.gov.

\section{REFERENCES}

1. Komar N, Panella NA, Langevin SA, Brault AC, Amador M, Edwards E, Owen JC, 2005. Avian hosts for West Nile virus in
St. Tammany Parish, Louisiana, 2002. Am J Trop Med Hyg 73: 1031-1037.

2. Komar N, Langevin S, Hinten S, Nemeth N, Edwards E, Hettler D, Davis B, Bowen R, Bunning M, 2003. Experimental infection of North American birds with the New York 1999 strain of West Nile virus. Emerg Infect Dis 9: 311-322.

3. Kilpatrick AM, LaDeau SL, Marra PP, 2007. Ecology of West Nile virus transmission and its impact on birds in the western hemisphere. Auk 124: 1121-1136.

4. Reisen WK, Fang Y, Martinez VM, 2005. Avian host and mosquito (Diptera: Culicidae) vector competence determine the efficiency of West Nile and St. Louis encephalitis virus transmission. J Med Entomol 42: 367-375.

5. Brown CR, Brown MB, 1995. Cliff Swallow (Hirundo pyrrhonota). Poole A, Gill F, eds. The Birds of North America. Philadelphia, PA: The Academy of Natural Sciences, 1-28.

6. Gubler DJ, 2007. The continuing spread of West Nile virus in the western hemisphere. Clin Infect Dis 45: 1039-1046.

7. United States Geological Survey, Historical West Nile Virus Maps. Available at: http://diseasemap.usgs.gov/wnv_historical.html. Accessed June 22, 2009.

8. Brown CR, Sethi RA, 2002. Mosquito abundance is correlated with cliff swallow (Petrochelidon pyrrhonota) colony size. J Med Entomol 39: 115-120.

9. Brown CR, Brown MB, 1996. Coloniality in the Cliff Swallow: The Effect of Group Size on Social Behavior. Chicago, IL: University of Chicago Press.

10. Stoner D, 1945. Temperature and growth studies of the northern cliff swallow. Auk 62: 207-216.

11. Nemeth NM, Hahn DC, Gould DH, Bowen RA, 2006. Experimental West Nile virus infection in eastern screech owls (Megascops asio). Avian Dis 50: 252-258.

12. Lanciotti RS, Kerst AJ, Nasci RS, Godsey MS, Mitchell CJ, Savage HM, Komar N, Panella NA, Allen BC, Volpe KE, Davis BS, Roehrig JT, 2000. Rapid detection of West Nile virus from human clinical specimens, field-collected mosquitoes, and avian samples by a TaqMan reverse transcriptase-PCR assay. J Clin Microbiol 38: 4066-4071.

13. Beaty BJ, Calisher CH, Shope RE, 1995. Diagnostic procedures for viral, rickettsial, and chlamydial infections. Lennette $\mathrm{EH}$, Lennette DA, Lennette ET, eds. Arboviruses. Washington, DC: American Public Health Association, 189-212.

14. Apperson CS, Hassan HK, Harrison BA, Savage HM, Aspen SE, Farajollahi A, Crans W, Daniels TJ, Falco RC, Benedict M, Anderson M, McMillen L, Unnasch TR, 2004. Host feeding patterns of established and potential mosquito vectors of West Nile virus in the eastern United States. Vector Borne Zoonotic Dis 4: 71-82.

15. Peterson AT, Vieglais DA, Andreasen JK, 2003. Migratory birds modeled as critical transport agents for West Nile virus in North America. Vector Borne Zoonotic Dis 3: 27-37.

16. Rappole JH, Hubálek Z, 2003. Migratory birds and West Nile virus. J Appl Microbiol 94: 47S-58S.

17. Nemeth NM, Beckett S, Edwards E, Klenk K, Komar N, 2007. Avian mortality surveillance for West Nile virus in Colorado. Am J Trop Med Hyg 76: 431-437.

18. Wheeler SS, Barker CM, Fang Y, Armijos MV, Carroll BD, Husted SR, Johnson WO, Reisen WK, 2009. Differential impact of West Nile virus on California birds. Condor 111: 1-20.

19. Dohm DJ, O'Guinn ML, Turell MJ, 2002. Effect of environmental temperature on the ability of Culex pipiens (Diptera: Culicidae) to transmit West Nile virus. J Med Entomol 39: 221-225.

20. Tiawsirisup S, Platt KB, Evans RB, Rowley WA, 2005. A comparison of West Nile virus transmission by Ochlerotatus trivittatus (COQ.), Culex pipiens (L.), and Aedes albopictus (Skuse). Vector Borne Zoonotic Dis 5: 40-47.

21. Turell MJ, O'Guinn M, Oliver J, 2000. Potential for New York mosquitoes to transmit West Nile virus. Am J Trop Med Hyg 62: 413-414.

22. Goddard LB, Roth AE, Reisen WK, Scott TW, 2002. Vector competence of California mosquitoes for West Nile virus. Emerg Infect Dis 8: 1385-1391.

23. Beveroth TA, Ward MP, Lampman RL, Ringia AM, Novak RJ, 2006. Changes in seroprevalence of West Nile virus across Illinois in free-ranging birds from 2001 through 2004. Am J Trop Med Hyg 74: 174-179. 
24. Godsey MS, Blackmore MS, Panella NA, Burkhalter K, Gottfried K, Halsey LA, Rutledge R, Langevin SA, Gates R, Lamonte KM, Lambert A, Lanciotti RS, Blackmore CGM, Loyless T, Stark L, Oliveri R, Conti L, Komar N, 2005. West Nile virus epizootiology in the southeastern United States, 2001. Vector Borne Zoonotic Dis 5: 82-89.

25. Komar N, Panella NA, Burns JE, Dusza SW, Mascarenhas TM, Talbot TO, 2001. Serologic evidence for West Nile virus infection in birds in the New York City vicinity during an outbreak in 1999. Emerg Infect Dis 7: 621-625.

26. Bolling BG, Moore CG, Anderson SL, Blair CD, Beaty BJ, 2007. Entomological studies along the Colorado front range during a period of intense West Nile virus activity. J Am Mosq Control Assoc 23: 37-46.

27. Kent R, Juliusson L, Weissmann M, Evans S, Komar N, 2009. Seasonal blood-feeding behavior of Culex tarsalis (Diptera: Culicidae) in Weld County, Colorado, 2007. J Med Entomol 46: 380-390.

28. Colton L, Nasci RS, 2006. Quantification of West Nile virus in the saliva of Culex species collected from the southern United States. J Am Mosq Control Assoc 22: 57-63.

29. Hutcheson HJ, Gorham $\mathrm{CH}$, Machain-Williams C, Lorono-Pino MA, James AM, Marlenee NL, Winn B, Beaty BJ, Blair CD, 2005. Experimental transmission of West Nile virus (Flaviviridae:
Flavivirus) by Carios capensis ticks from North America. Vector Borne Zoonotic Dis 5: 293-295.

30. Lawrie CH, Uzcategui NY, Gould EA, Nuttall PA, 2004. Ixodid and argasid tick species and West Nile virus. Emerg Infect Dis 10: 653-657.

31. Loye J, 1985. The life history and ecology of the cliff swallow bug, Oeciacus vicarius (Hemiptera: Cimicidae). Cah ORSTOM Ser Entomol Med Parasitol 23: 133-139.

32. Nemeth NM, Oesterle PT, Bowen RA, 2008. Passive immunity to West Nile virus provides limited protection in a common passerine species. Am J Trop Med Hyg 79: 283-290.

33. Nemeth NM, Bowen RA, 2007. Dynamics of passive immunity to West Nile virus in domestic chickens (Gallus gallus domesticus). Am J Trop Med Hyg 76: 310-317.

34. Brown CR, Moore AT, Knutie SA, Komar N, 2009. Overwintering of infectious Buggy Creek virus (Togaviridae: Alphavirus) in Oeciacus vicarius (Hemiptera: Cimicidae) in North Dakota. J Med Entomol 46: 391-394.

35. Nemeth N, Gould D, Bowen R, Komar N, 2006. Natural and experimental West Nile virus infection in five raptor species. $J$ Wildl Dis 42: 1-13.

36. Nemeth N, Young G, Ndaluka C, Bielefeldt-Ohmann H, Komar N, Bowen R, 2009. Persistent West Nile virus infection in the house sparrow (Passer domesticus). Arch Virol 154: 783-789. 